\title{
Original Research \\ Understory Flora in Relation to Canopy Structure, Soil Nutrients, and Gap Light Regime: a Case Study in Southern China
}

\author{
Zhi-Yang Ou*, Ji-Zhao Cao, Wen-Hui Shen, Yi-Bo Tan, Qin-Fei He, Yu-Hua Peng \\ Guangxi Forestry Research Institute, Nanning 530002, China
}

Received: March 19, 2015

Accepted: August 27, 2015

\begin{abstract}
To better understand the contribution of understory to biodiversity of a forest ecosystem, we examined the understory in stands of: (1) a Phyllostachys edulis (Moso bamboo) plantation, (2) a Cunninghamia lanceolata (Chinese fir) plantation and (3) a natural evergreen and deciduous broad-leaved mixed forest (natural mixed forest) in Mt. Mao'er in southern China, and the distribution and diversity of understory in relation to environmental conditions (overstory structure, soil nutrients, and gap light level). Soil samples were taken and analyzed in a laboratory for $\mathrm{pH}$, organic matter (SOM), and total nitrogen (TN). Hemispherical photographs were taken using a Panasonic DMC-LX5 digital camera and analyzed using Gap Light Analyzer 2.0 software. Statistical methods, such as multi-response permutation procedure (MRPP), detrended correspondence analysis (DCA), Mantel test, and stepwise multiple linear regressions were used in this study. Canopy communities were significantly different in basal area $(B A)$, density, and species richness but not Shannon diversity $\left(H^{\prime}\right)$. Soil variables differed in terms of soil $\mathrm{pH}$ and TN across the three canopy types; however, the light levels did not differ significantly. MRPP revealed significant differences in species composition of understory among the three forest types. DCA ordination separated sample plots into three groups corresponding to the three forest types. Multiple stepwise regressions showed that soil $\mathrm{pH}$ combined with SOM, Overstory- $H^{\prime}$ and TTot could explain $99 \%$ of the variation in understory species richness, while Overstory- $H^{\prime}$ with Overstory- $S$, Density, and SOM could explain $92 \%$ of the variation in understory diversity. The results indicated that canopy structure together with soil nutrient were the best predictors of understory vegetation in the study area.
\end{abstract}

Keywords: understory flora, woody plant canopy, light level, soil properties, plant diversity

\section{Introduction}

Both canopy tree and understory plants are important ecological components in most forest ecosystems. Trees affect species composition and diversity pattern of the understory by modifying resource levels (such as light regimes, soil properties, and water availability) beneath their canopies $[1,2]$. Deeply rooted trees transport water to shallow roots via the process of hydraulic redistribution

*e-mail: ozhiyang@126.com during the drought season [3], acquire nutrients from deeper soil layers, and redistribute them at the surface through litter fall [4]. The resources available for understory plants vary with the differences in diversity and structure of the forest overstory $[5,6]$. Therefore, a mixed overstory can increase resource heterogeneity and partitioning in the understory [7]. Canopy trees also directly compete with understory plants for light, water, and soil nutrients $[8,9]$, which limits the distribution and biomass of understory plants. Although the volume of the understory carbon pool is limited, its turnover rate is more rapid than that of the 
trees [10]. Moreover, because understory plants can integrate the effect of climate, soil, light, and physiography, they may be used as indicators for habitat conditions [11, 12]. So far, several studies have focused on the effects of overstory on understory vegetation and environmental conditions [13-16], relationships between the floristic composition and diversity of understory communities and environmental factors [17-19], and responses of understory vegetation to disturbance $[20,21]$. However, by overemphasizing the role of overstory trees, potential contribution of the understory to forest biodiversity conservation is still poorly understood in many ecosystems, and our current knowledge about the overstory-understory relationship is also limited.

Mt. Mao'er is located in northeastern Guangxi in southern China, stretching from Longsheng, Xing'an to Ziyuan County, with a total area of $17,008.5 \mathrm{hm}^{2}$. The main peak of Mt. Mao'er is known as the "Peak of South China," with an altitude of 2,141.5 $\mathrm{m}$ a.s.1. Given its status as one of 16 biodiversity hot spots, one of the 14 key areas of land biodiversity with international significance in China, and the source of the famous Lijiang River, many studies have focused on plant community species composition, diversity, community pattern, hydrological characteristics, and water conservation function there [22-26]. Forests in Mt. Mao'er have high species richness, yet we have little information about the understory communities present and their contributions to the ecological processes of the forest ecosystem. Therefore, our objectives are:

(i) to quantify and compare the understory species composition in three stands with contrasting woody plant canopies in Mt. Mao'er

(ii) to relate the spatial distribution and diversity of understory to canopy structure, soil fertility, and light availability.

\section{Material and Methods}

\section{Study Area}

The study was located in Mt. Mao'er National Nature Reserve $\left(25^{\circ} 48^{\prime}-25^{\circ} 58^{\prime} \mathrm{N}\right.$ and $\left.110^{\circ} 20^{\prime}-110^{\circ} 35^{\prime} \mathrm{E}\right)$ in Guangxi, South China. Mt. Mao'er is situated in the midsubtropical moist climate region. The mean annual temperature is $12.8^{\circ} \mathrm{C}$, with minimum and maximum temperatures varying from -15.0 to $29.5^{\circ} \mathrm{C}$. The mean annual precipitation, relative humidity, and sunshine hours are 2,509.1 mm, $92.0 \%$, and $1,065.7 \mathrm{~h}$, respectively. The accumulated temperature greater than or equal to $10^{\circ} \mathrm{C}$ is $4,229.7^{\circ} \mathrm{C}$ [27]. The soil parent material is granite. Soil distribution from the foot to the top of mountain is mountainous red soil (below $400 \mathrm{~m}$ a.s.1.), yellow red soil (400-700 $\mathrm{m}$ a.s.1.), yellow soil (700-1200 m a.s.1.), grassing brown soil (1,200-1,400 m a.s.1.), yellow brown soil (1,400-1,800 $\mathrm{m}$ a.s.1.), and coppice soil (above 2,000 $\mathrm{m}$ a.s.1.).

The vegetation distribution in Mt. Mao'er shows a vertical zonation. Evergreen coniferous and broad-leaved mixed plantations, bamboo, and coniferous plantations are mainly distributed below $600 \mathrm{~m}$ a.s.l. Forests distributed in an elevation range from 600 to $900 \mathrm{~m}$ a.s.l. are mainly evergreen broad-leaved forests dominated by Cinnamomum appelianum, Ternstroemia gymnanthera, and bamboo and coniferous plantations. Forests dispersed from 900 to 1,300 $\mathrm{m}$ a.s.l. are mostly evergreen broad-leaved forests dominated by Castanopsis fabric, Lithocarpus calophyllus and Halesia macgregorii, and bamboo and coniferous plantations. Evergreen and deciduous broad-leaved mixed forest with partial evergreen broad-leaved forests are distributed from 1,300 to $1,700 \mathrm{~m}$ a.s.l., and forests spreading from 1,700 to $2,000 \mathrm{~m}$ a.s.l. mainly are evergreen and deciduous broad-leaved mixed forest and evergreen broad-leaved mixed conifer forest. Montane elfin forest is mainly distributed above 2,000 $\mathrm{m}$ a.s.l.

In June-July 2013 we established nine plots for a canopy tree survey, consisting of three plots for the Phyllostachys edulis (Moso bamboo) plantation near Jiuniutang $\left(25^{\circ} 53^{\prime} 1^{\prime \prime} \mathrm{N}\right.$ and $110^{\circ} 29^{\prime} 16^{\prime \prime} \mathrm{E}$, and 1,150 m a.s.1.), three plots for the Cunninghamia lanceolata

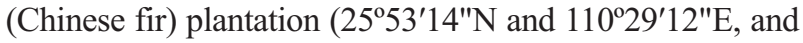
$1,152 \mathrm{~m}$ a.s.1.), and three plots for the natural evergreen and deciduous broad-leaved mixed forest (Natural mixed forest) $\left(25^{\circ} 54^{\prime} 21^{\prime \prime} \mathrm{N}\right.$ and $110^{\circ} 27^{\prime} 55^{\prime \prime} \mathrm{E}$, and 1,384 $\mathrm{m}$ a.s.l.). Moso bamboo and Chinese fir, fast-growing commercial timbers in subtropical China, are the main ecological economic species planted in Mt. Mao'er and adjacent areas. In the study area, Moso bamboo and Chinese fir had been planted for decades, while anthropogenic disturbance for the two plantations had been gradually reduced since the Mt. Mao'er Nature Reserve was established in 1976. The natural mixed forest is an old-growth forest, mainly dominated by the relic plant of Tertiary, Fagus longipetiolata, maintaining abundant plant diversity.

\section{Plant Census}

Field surveys and measurements were conducted in June and July 2013. Within sample plots, all woody plants with diameters at breast height $(\mathrm{DBH}) \geq 6 \mathrm{~cm}$ per plot were tallied, and their species identified; height (measured to the nearest $0.1 \mathrm{~m}$ ), and DBH (measured to the nearest to $0.1 \mathrm{~cm}$ ) were recorded. Details of overstory species composition and canopy characteristics are found in Table 1 .

Five $2 \times 2 \mathrm{~m}$ subplots were established in each plot - one in the center and at each of the four corners of the $20 \times 20 \mathrm{~m}$ plot. Understory vascular plants in each subplot were counted as the number of individuals, coverage, and average height of each species. Data from the five subplots were summed to represent a plot. Thus, a total of 45 subplots ( 3 canopy types $\times 3$ plots $\times 5$ subplots) were sampled.

\section{Soil Sampling and Hemispherical Photography}

Soil samples were collected in each subplot at two depths $(0-10$ and $10-20 \mathrm{~cm})$. Soils from the two depths of each plot were summed, and about $1 \mathrm{~kg}$ mixed samples were sealed in plastic bags and analyzed at the Soil Testing Laboratory at the Soil \& Fertilizer Research Division of 
Table 1. Summary of overstory species composition for the three communities in Mt. Mao'er, Guangxi*.

\begin{tabular}{|c|c|c|c|}
\hline Species & $\begin{array}{c}\text { Moso } \\
\text { bamboo } \\
\text { plantation }\end{array}$ & $\begin{array}{l}\text { Chinese } \\
\text { fir } \\
\text { plantation }\end{array}$ & $\begin{array}{l}\text { Natural } \\
\text { mixed } \\
\text { forest }\end{array}$ \\
\hline Acer davidii & 0.19 & 0.12 & 0.09 \\
\hline Acer palmatum & 0.02 & & \\
\hline Alniphyllum fortunei & & 0.05 & \\
\hline Betula alnoides & & & 0.22 \\
\hline Castanopsis lamontii & & & 1.15 \\
\hline Castanopsis tonkinensis & 0.39 & & \\
\hline Cleidion brevipetiolatum & & & 0.28 \\
\hline Clethra cavaleriei & & & 0.08 \\
\hline Cornus wilsoniana & & 0.17 & \\
\hline Cunninghamia lanceolata & 1.54 & 41.62 & \\
\hline Cyclobalanopsis nubium & & & 0.02 \\
\hline Daphniphyllum macropodum & 0.33 & & 2.36 \\
\hline Endospermum chinense & & 0.19 & \\
\hline Enkianthus quinqueflorus & & & 0.03 \\
\hline Eurya loquiana & & & 0.14 \\
\hline Evodia daniellii & & & 0.04 \\
\hline Fagus longipetiolata & 0.03 & & 17.23 \\
\hline Ficus heteromorpha & & 0.03 & \\
\hline Ilex angulata & & & 0.19 \\
\hline Ligustrum quihouri & & & 0.02 \\
\hline Liquidambar formosana & & & 0.06 \\
\hline Litsea cubeba & 0.10 & & \\
\hline Litsea elongata & & & 0.23 \\
\hline Macaranga denticulata & & 0.07 & \\
\hline Machilus leptophylla & 0.09 & & \\
\hline Machilus pauhoi & 0.22 & & \\
\hline Maesa japonica & & & 0.77 \\
\hline Neolitsea aurata & & & 0.13 \\
\hline Nyssa sinensis & 0.04 & & 0.05 \\
\hline Phyllostachys edulis & 18.10 & 2.41 & \\
\hline Rhamnus leptophylla & 0.02 & & \\
\hline Rhododendron fortunei & 0.33 & & \\
\hline Rhododendron latoucheae & 0.12 & & 0.34 \\
\hline Rhododendron orbiculare & & & 0.03 \\
\hline Rhododendron simiarum & & & 0.04 \\
\hline Rhododendron simsii & 0.02 & & 0.02 \\
\hline Sassafras tsumu & & 0.62 & 0.60 \\
\hline Symplocos anomala & & & 0.88 \\
\hline Symplocos glauca & & & 0.04 \\
\hline Canopy closure & sparse & very dense & very dense \\
\hline Canopy architecture & $\begin{array}{c}\text { narrow } \\
\text { lanceolate }\end{array}$ & $\begin{array}{c}\text { narrow } \\
\text { coniferous }\end{array}$ & $\begin{array}{l}\text { spreading } \\
\text { broadleaf }\end{array}$ \\
\hline
\end{tabular}

*values are average basal area $\left(B A, \mathrm{~m}^{2} \cdot \mathrm{ha}^{-1}\right)$
Guangxi Forestry Research Institute. Soil pH values were measured with a $\mathrm{pH}$ meter. Content of soil organic matter $(\mathrm{SOM})$ and total nitrogen $(\mathrm{TN})$ were measured using potassium dichromate and distillation methods, respectively.

Hemispherical photographs were taken using a DMCLX5 digital camera (Panasonic Corporation, Tokyo, Japan) with an upward-looking FC-E8 fisheye lens converter (Nikon Corporation, Tokyo, Japan). The camera was set on a self-leveling Mid-O-Mount with an inner North Finder on a tripod at the height of $1.5 \mathrm{~m}$, oriented to magnetic north by the self-leveling Mid-O-Mount using a remote control. A single photograph was taken at the center, one-fourth, and three-fourth points on the diagonal of each sample plot. Up to 45 photos were taken and saved in fine-quality JPEG format. All photographs were taken on clear days before 11 a.m. and after 3 p.m., or on overcast days to minimize the glare from direct sunlight. The hemispherical images were analyzed using Gap Light Analyzer (GLA, version 2.0) [28]. In GLA, analyzing the photos requires a threshold value to be determined by the user. Pixels darker than the threshold value are separated into "canopy," and pixels lighter than this value are separated into "sky" [29]. Three parameters were selected, representing the transmitted gap light regime in the understory. Leaf area index (LAI) is computed for effective leaf area index integrated over the zenith angles $0-60^{\circ}$; percent canopy openness (CO) is computed for the percentage of open sky seen from beneath a forest canopy, and percent trans total (TTot) is computed for the ratio of amount of total solar radiation transmitted by the canopy and topographic mask to the above total mask multiplied by $100 \%$.

\section{Data Analysis}

The importance value (IV) of each understory species per plot was calculated by summing the relative frequency, relative density, and relative cover (maximum 300\%) [4]. Community characteristics, including the basal area $(B A)$ and density (Density) of overstory trees, number of individuals $(N)$, Shannon diversity index $\left(H^{\prime}\right)$, species richness $(S)$, and evenness for overstory and understory flora were computed using statistical software PC-ORD 5.0. The diversity parameters were calculated according to the following equations:

$$
\begin{gathered}
S=\text { number of species per plot } \\
N=\sum N_{i} \\
H^{\prime}=-\sum_{i=1}^{s} p_{i} \ln p_{i} \\
E=H^{\prime} / \ln S
\end{gathered}
$$

...where: $N_{i}$ - number of stems per plot and $p_{i}$ - proportion of the number of the $i$-th species to the total number of species in the $j$-th plot.

Three datasets were constructed based on data collected from the 45 subplots: understory-flora presence/absence data, IV of understory component species in each plot, and a quantitative environmental data matrix, comprising $B A$, 
density, the Shannon diversity index (Overstory- $H^{\prime}$ ), and species richness (Overstory- $S$ ) of overstory trees, soil $\mathrm{pH}$, SOM, TN, CO, LAI, and TTot. We performed multiresponse permutation procedures (MRPP) to test for differences in understory species composition (as presence/ absence) among forests. Paired analysis was conducted to compare two groups ( $\mathrm{p}$-values below 0.05 were considered significant). The Mantel test with the Sorensen distance measure was used to compare understory species compositions. Probability levels for the Mantel tests were calculated using 5000 Monte-Carlo randomizations. The Mantel test can compare only two matrices at a time and it is undesirable to include all variables in the same matrix; therefore, we ran independent tests for each variable, with a correction factor applied to the resultant p-values [30].

Individual species IVs and sample plots were ordinated by detrended correspondence analysis (DCA). Pearson's and Kendall's Tau correlation coefficients were calculated to identity associations between ordination scores and the explanatory environmental variables. All of the above multivariate analyses were performed by PCORD Version 5.0.

Data of overstory characteristics and environmental factors were analyzed by one-way ANOVA followed by Duncan multiple range tests, with the level of significance set at $p<0.05$. Finally, forward stepwise multiple regressions were performed in SPSS Version 19.0 to identify environmental factors related to plant diversity in understory.

\section{Results and Discussion}

\section{Community Characteristics}

A canopy of natural mixed forest can be stratified into three sublayers according to tree height. The first sublayer is about $20 \mathrm{~m}$, mainly dominated by evergreen broadleaved species, Castanopsis lamontii, and deciduous broadleaved species, Fagus longipetiolata; the second is about 8-15 $\mathrm{m}$, with no obvious dominant species; the third is about 4-7 $\mathrm{m}$ with discontinuous canopy, mainly dominated by evergreen broad-leaved species [31]. Compared to natural mixed forest, Moso bamboo and Chinese fir plantation comprise only one layer in the canopy. Community structure of the natural mixed forest is more complex with significantly stratified canopy than that of Moso bamboo and Chinese fir plantation, yet the two plantations are tall and dense for a given stem diameter, and they have narrower crown for a given height than old-growth trees.

A total of 95 understory species, distributed in 77 genera and 50 families, was recorded across all plots. The Moso bamboo plantation had 48 species in 33 families, the Chinese fir plantation had 28 species in 19 families, and the natural mixed forest had 50 species in 35 families (dominant taxa shown in Table 2). Sixty-seven species were unique to only one of the forest types. Natural mixed forest had the highest number of unique species (34), and Moso bamboo plantation had the least (12). Although Carex cruciata, Cayratia japonica, Eurya groffii, and Ficus heteromorpha were common to all forest stands, they accounted for only $4.2 \%$ of the total number of understory species. Arthraxon hispidus dominated the understory of the Moso bamboo plantation with the highest IV, and Cyclosorus parasiticus and Carex cruciata dominated the understory of the Chinese fir plantation and the natural mixed forest (Table 2). The forests also differed in co-dominant species. Strobilanthes penstemonoides, Arthraxon hispidus, and Oplismenus compositus was co-dominant in Moso bamboo, Chinese fir, and Natural mixed forest, respectively.

We found that the Chinese fir plantation provides the least, but natural mixed forest the greatest vascular understories (Table 2). Several studies have also observed that conifer-dominated forests had the least species in understory $[32,33]$, richness was the greatest for mixed patch types, followed by gaps, and then conifer and broadleaf patch types [34]. Studies demonstrated that natural stands with stratified canopy have the highest understory species richness, while single-layered stands had consistently low understory [35-37]. These studies reveal that mixed stands could maintain more diverse species in understory than those with single structure, and species richness and composition patterns of understory are strongly associated with forest stand type $[38,39]$.

\section{Characteristics of Overstory and Environmental Factors}

Mean overstory basal area $(B A)$ of Moso bamboo and natural mixed forest were significantly lower than that of the Chinese fir plantation ( $p<0.05$; Fig. 1A). Tree densities of the three canopies were significantly different (overall $\mathrm{p}<0.05$ ), with Moso bamboo plantation $>$ Chinese fir plantation and natural mixed forest. Overstory- $H^{\prime}$ of natural mixed forest was the highest, but not significantly different among forest stands $(\mathrm{p}=0.2014)$. The overstory species richness of natural mixed forest was significantly higher than that of the two plantations (overall $\mathrm{p}<0.05$ ).

Of the other environmental factors, significant differences were found only in $\mathrm{pH}$ and TN (Table 3): Moso bamboo plantation had the highest $\mathrm{pH}$ and lowest $\mathrm{TN}$, natural mixed forest had the lowest $\mathrm{pH}$ and highest $\mathrm{TN}$, while Chinese fir was intermediate.

\section{Multi-Response Permutation Procedures}

Studies have revealed that forests with contrasting canopy structures support distinct understory communities [40-42]. In the present study, significant differences in understory species composition were determined by MRPP $(\mathrm{T}=-4.0619, \mathrm{~A}=0.1937, \mathrm{p}=0.0009$ ). Pairwise comparisons with MRPP showed significant differences among the three canopy types, with the difference being the greatest between Chinese fir plantation and natural mixed forest (Table 4). Mantel tests showed that dissimilarity in understory species composition was negatively associated with LAI and Overstory- $H^{\prime}$, and positively with $B A$, density, and 
Table 2. Dominant understory species in Moso bamboo, Chinese fir, and natural mixed forest.

\begin{tabular}{|c|c|c|c|c|}
\hline Species & Family & Moso bamboo plantation & Chinese fir plantation & Natural mixed forest \\
\hline Arthraxon hispidus & Agrostidoideae & 53.15 & 38.93 & 0.00 \\
\hline Carex cruciata & Cyperaceae & 0.00 & 0.00 & 36.99 \\
\hline Camellia sinensis & Theaceae & 0.00 & 29.71 & 0.00 \\
\hline Cyclosorus parasiticus & Thelypteridaceae & 0.00 & 58.54 & 0.00 \\
\hline Ficus heteromorpha & Moraceae & 35.26 & 0.00 & 0.00 \\
\hline Fordiophyton fordii & Melastomaceae & 0.00 & 0.00 & 31.24 \\
\hline Impatiens siculifer var porphyrea & Balsaminaceae & 27.27 & 0.00 & 0.00 \\
\hline Indocalamus tessellatus & Bambusoideae & 0.00 & 0.00 & 25.81 \\
\hline Notoseris psilolepis & Compositae & 34.67 & 0.00 & 0.00 \\
\hline Oplismenus compositus & Agrostidoideae & 0.00 & 0.00 & 35.82 \\
\hline Pilea cordistipulata & Urticaceae & 0.00 & 0.00 & 32.06 \\
\hline Polygonatum sibiricum & Liliaceae & 0.00 & 34.85 & 0.00 \\
\hline Rubus columellaris & Rosaceae & 34.43 & 0.00 & 0.00 \\
\hline Selaginella uncinata & Selaginellaceae & 0.00 & 0.00 & 26.38 \\
\hline Strobilanthes penstemonoides & Acanthaceae & 36.49 & 0.00 & 0.00 \\
\hline Viburnum dilatatum & Caprifoliaceae & 0.00 & 27.78 & 0.00 \\
\hline \multicolumn{2}{|l|}{ Total number of species } & 48 & 28 & 50 \\
\hline \multicolumn{2}{|l|}{ Mean species richness } & 23.3 & 13.3 & 24.0 \\
\hline \multicolumn{2}{|l|}{ Mean $\mathrm{H}^{\prime}$} & 1.584 & 1.801 & 2.293 \\
\hline \multicolumn{2}{|l|}{ No. of unique species } & 21 & 12 & 34 \\
\hline
\end{tabular}

A)

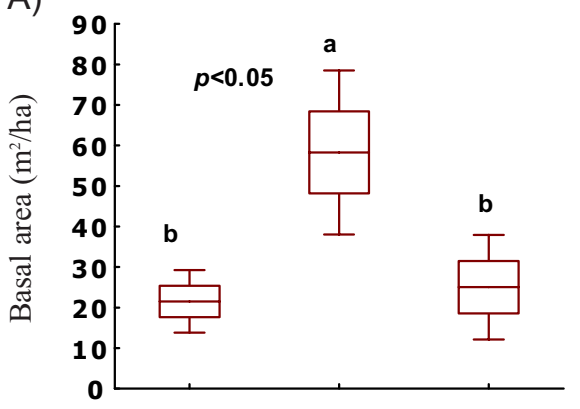

C)

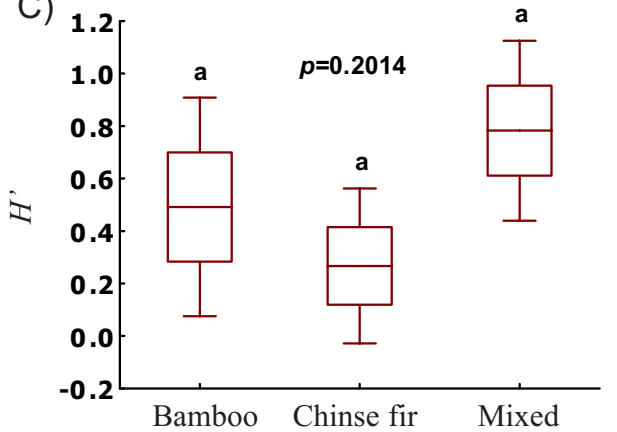

B)

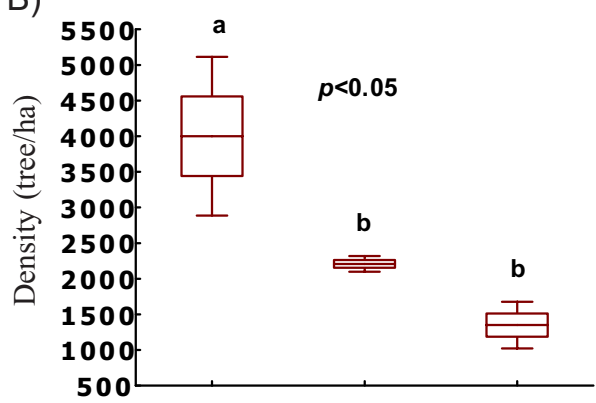

D)

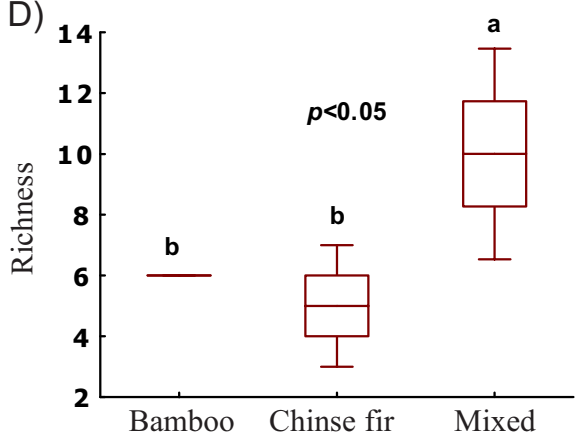

Canopy types

Fig. 1. Summary of overstory characteristics. Basal area (A), density (B), Shannon diversity index (C), and species richness (D). Bars with different lower-case letters are significantly different at $\mathrm{p}<0.05$. 
Table 3. Site factors and canopy structure of the three woody plant canopies.

\begin{tabular}{|c|c|c|c|c|}
\hline & & Moso bamboo plantation & Chinese fir plantation & Natural mixed forest \\
\hline \multirow{2}{*}{$\begin{array}{l}\text { Canopy openness } \\
(\%, \mathrm{CO})\end{array}$} & Range & $14.873-17.138$ & $12.354-16.843$ & $12.261-16.531$ \\
\hline & Mean \pm SE & $15.70 \pm 0.72^{\mathrm{a}}$ & $14.33 \pm 1.32^{\mathrm{a}}$ & $14.30 \pm 1.24^{\mathrm{a}}$ \\
\hline \multirow{2}{*}{$\begin{array}{l}\text { Leaf area index } \\
\text { (LAI) }\end{array}$} & Range & $1.776-2.318$ & $1.952-2.516$ & $2.223-2.456$ \\
\hline & Mean \pm SE & $2.06 \pm 0.16^{\mathrm{a}}$ & $2.23 \pm 0.16^{\mathrm{a}}$ & $2.32 \pm 0.07^{\mathrm{a}}$ \\
\hline \multirow{2}{*}{$\begin{array}{l}\text { Trans total } \\
(\%, \text { TTot })\end{array}$} & Range & $21.467-26.995$ & $18.249-28.366$ & $19.064-22.913$ \\
\hline & Mean \pm SE & $24.92 \pm 1.74^{\mathrm{a}}$ & $22.82 \pm 2.96^{\mathrm{a}}$ & $20.85 \pm 1.12^{\mathrm{a}}$ \\
\hline \multirow{2}{*}{$\mathrm{pH}$} & Range & $4.83-5.03$ & $4.3-4.65$ & $4.08-4.11$ \\
\hline & Mean \pm SE & $4.94 \pm 0.06^{\mathrm{a}}$ & $4.50 \pm 0.10^{\mathrm{b}}$ & $4.10 \pm 0.01^{\mathrm{c}}$ \\
\hline \multirow{2}{*}{$\begin{array}{l}\text { Soil organic matter } \\
\left(\mathrm{SOM}, \mathrm{g} \cdot \mathrm{kg}^{-1}\right)\end{array}$} & Range & $85.65-121.02$ & $93.37-123.98$ & $112.73-183.89$ \\
\hline & Mean \pm SE & $103.27 \pm 10.21^{\mathrm{a}}$ & $109.55 \pm 8.88^{\mathrm{a}}$ & $149.39 \pm 20.57^{\mathrm{a}}$ \\
\hline \multirow{2}{*}{$\begin{array}{l}\text { Total nitrogen } \\
\left(\mathrm{TN}, \mathrm{g} \cdot \mathrm{kg}^{-1}\right)\end{array}$} & Range & $1.25-4.26$ & $4.04-5.27$ & $4.84-8.07$ \\
\hline & Mean \pm SE & $3.08 \pm 0.93^{\mathrm{b}}$ & $4.68 \pm 0.36^{\mathrm{ab}}$ & $6.40 \pm 0.93^{\mathrm{a}}$ \\
\hline
\end{tabular}

Means with the same letter within a row are not significantly different at $\mathrm{p}=0.05$.

Table 4. MRPP pairwise comparisons of understory species composition among different canopy types

\begin{tabular}{|c|c|c|c|}
\hline Compared group & T-statistic ${ }^{\mathrm{a}}$ & A-statistic ${ }^{b}$ & p-value ${ }^{c}$ \\
\hline Bamboo vs. Chinese fir & -2.355 & 0.137 & 0.026 \\
\hline Bamboo vs. Natural mixed forest & -2.371 & 0.133 & 0.027 \\
\hline Chinese fir vs. Natural mixed forest & -2.832 & 0.208 & 0.023 \\
\hline
\end{tabular}

${ }^{a}$ Separation between groups by Sorensen (Bray-Curtis) distance; the separation tends to be stronger with more negative value.

${ }^{b}$ Describe within-group similarity; the value ranges from 0 to 1 , with value of 1 indicating identical items within groups.

${ }^{\mathrm{c}}$ Indicate the significance level of the corresponding T-statistic.

soil $\mathrm{pH}$ (Table 5). This may be attributed to the influence of the species composition and structure of overstory on the understory resource levels and distribution, which in turn influence the distribution of understory species. There is also evidence that site's geographic and geological characteristics and forest management influence the ground flora more than the tree species at a larger spatial scale [43]. The influence of factors on species recruitment, e.g., seed dispersal, germination ecology, and seedling survival, are important but rarely quantified [44-46].

Table 5. Significant association between species composition of understory and site factor matrices as determined by independent Mantel tests. All $\mathrm{R}$ values are significant at $\mathrm{p}<0.05$.

\begin{tabular}{|l|c|c|}
\hline \multicolumn{1}{|c|}{ Variable } & $\mathrm{R}$ & $\mathrm{p}$ \\
\hline Overstory BA & 0.304 & 0.037 \\
\hline Overstory-H' & -0.230 & 0.027 \\
\hline Overstory Density & 0.515 & 0.002 \\
\hline Soil $\mathrm{pH}$ & 0.428 & 0.009 \\
\hline LAI & -0.283 & 0.017 \\
\hline
\end{tabular}

\section{Detrended Correspondence Analysis}

DCA ordination separated sample plots into three groups corresponding to the three forest types (Fig. 2). There was a clear gradient on Axis 1 from plots with fewer species (lower scores) to plots with more species in the tree layer on the right (higher scores). Our results are similar to those of Sagar et al. [4], who found a separation of herbaceous assemblages corresponding to three woody plant canopies. Overstory- $S$ was strongly correlated with the first DCA axis ( $\mathrm{r}=0.837)$ (Table 6), as was the Shannon diversity index (Overstory- $\left.H^{\prime}\right)$ and basal area $(B A)$. However, the light parameters were not strongly related to the first DCA axis, only TTot was weakly correlated with the second DCA axis $(\mathrm{r}=0.501)$.

Studies have revealed that overstory structure plays a leading role in determining understory distribution [47, 48], which affects understory communities through direct influence on soil nutrient availability, sub-canopy light level, and microclimate [49-51]. We found that the overstory characteristic was the most important factor related to the variation of understory species distribution, as was soil fertility (as inferred by data on soil $\mathrm{TN}$ and $\mathrm{pH}$ ). The reason may be that canopy characteristics determine the resulting 
Table 6. Pearson and Kendall's tau correlations between the first two DCA ordination axis and site variables.

\begin{tabular}{|c|c|c|c|c|c|c|}
\hline \multirow{2}{*}{ Site variable } & \multicolumn{3}{|c|}{ Axis 1} & \multicolumn{3}{|c|}{ Axis 2} \\
\hline & $\mathrm{r}$ & $r^{2}$ & tau & $\mathrm{r}$ & $r^{2}$ & tau \\
\hline BA & $\underline{-0.585}$ & 0.342 & -0.389 & -0.033 & 0.001 & 0.000 \\
\hline Density & -0.366 & 0.134 & -0.167 & -0.358 & 0.128 & -0.222 \\
\hline Overstory-H' & $\underline{0.641}$ & 0.411 & 0.500 & 0.303 & 0.092 & 0.222 \\
\hline Overstory-S & $\underline{0.837}$ & 0.701 & 0.784 & 0.060 & 0.004 & 0.065 \\
\hline $\mathrm{pH}$ & $\underline{-0.573}$ & 0.328 & -0.222 & -0.039 & 0.002 & -0.056 \\
\hline SOM & $\underline{0.565}$ & 0.319 & 0.278 & 0.130 & 0.017 & -0.111 \\
\hline $\mathrm{TN}$ & 0.477 & 0.228 & 0.333 & 0.043 & 0.002 & 0.056 \\
\hline $\mathrm{CO}$ & -0.033 & 0.001 & -0.056 & 0.164 & 0.027 & 0.222 \\
\hline LAI & 0.232 & 0.054 & 0.111 & 0.143 & 0.020 & 0.056 \\
\hline TTot & -0.362 & 0.131 & -0.278 & $\underline{0.501}$ & 0.251 & 0.444 \\
\hline
\end{tabular}

Data with underline indicate that the correlation coefficients are over 0.500

Table 7. Forward stepwise regression models depicting the relationship between site factors and indices of understory plant diversity.

\begin{tabular}{|l|c|c|c|}
\hline \multicolumn{1}{|c|}{ Model } & $\mathrm{r}^{2}$ & $\mathrm{~F}$ & $\mathrm{p}$ \\
\hline Understory- $S=-132.58+0.392 \mathrm{SOM}+25.209 \mathrm{pH}+6.763$ Overstory- $H^{\prime}-0.511 \mathrm{TT}$ tot & 0.99 & 74.79 & 0.0005 \\
\hline Understory-Evenness $=0.922+0.114$ Overstory- $H^{\prime}-0.001 \mathrm{SOM}$ & 0.47 & 2.63 & 0.1512 \\
\hline Understory- $H^{\prime}=-0.068+0.682$ Overstory- $H^{\prime}-0.040$ Overstory- $S+0.0003$ Density+0.014SOM & 0.92 & 10.95 & 0.0198 \\
\hline
\end{tabular}

soil nutrient availability through affecting the amount and composition of leaf litter produced [52], and thus the understory distribution. An overstory with high richness forms a heterogeneous canopy structure, which provides diverse microhabitats for understory species with different requirements.

\section{Stepwise Regression Analysis}

Results from forward stepwise regression analysis demonstrated that characteristics of the understory (Understory- $S$, Understory- $H^{\prime}$ ) are best predicted by some of the measured environmental parameters (Table 7); SOM

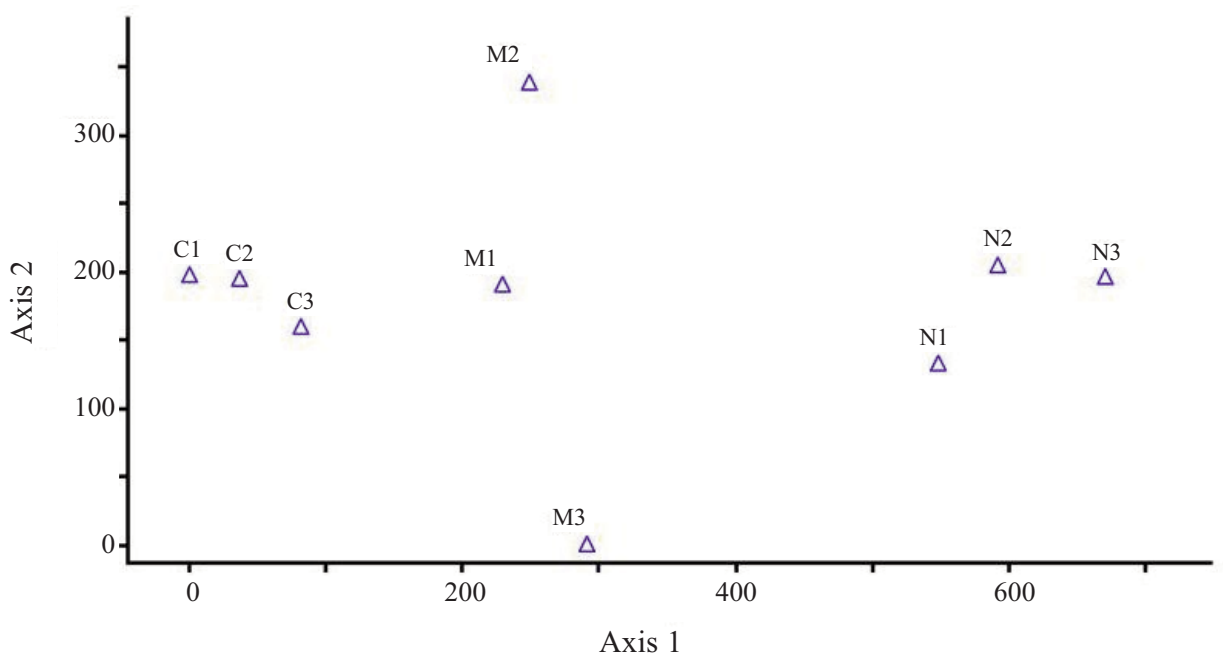

Fig. 2. DCA ordination of plots based on importance value indices of the understory species under three woody plant canopies. Forest types are indicated by capital letters $(\mathrm{C} 1, \mathrm{C} 2$, and $\mathrm{C} 3$ - representing three plots of Chinese fir, M1, M2 and M3 and N1, N2 and N3, respectively, for three plots each of Moso bamboo plantation and natural mixed forest). 
and Overstory- $H^{\prime}$ occur more often than others in the final models. SOM, $\mathrm{pH}$, and Overstory- $H^{\prime}$ together with TTot could explain $99 \%$ of the variation in understory species richness (Understory- $S$ ). The model for evenness (Understory-Evenness), which identified Overstory- $H^{\prime}$ and SOM, was not significant $(\mathrm{p}=0.1512)$. Understory- $H^{\prime}$ was best predicted $\left(92 \%\right.$ of variation) by Overstory- $H^{\prime}$, Overstory- $S$, Density, and SOM.

Previous studies demonstrated that understory community and diversity are closely related to soil nutrients [53, 54], overstory characteristics [55-57], and light availability $[58,59]$. In the present study, variation in the understory species diversity was mainly correlated with overstory and soil properties, while effect of light level was relative weak. Presumably the heterogeneous microhabitat caused by the species-rich and complex canopy structure and fertile soil alleviates the effect of light, so that light is not a limiting factor.

\section{Conclusions}

In this study, the three forest types differed in overstory tree composition, canopy structure, and soil conditions, supporting the distinct differences in understory species composition. The understory alpha diversities of natural mixed forest plots were higher than that of the two plantations (Table 2), demonstrating that natural forests had greater ecological importance than plantations in controlling understory communities.

Our results revealed that variation in understory communities were mainly correlated with overstory and soil properties. In summary, overstory sinusia properties, together with edaphics, play a significant role in determining the understory communities. Meanwhile, understory in this area is more constrained by aboveground competition (i.e. low light availability under dense canopy cover) than belowground competition (for fertile soil nutrients) [60, 61]. Understory flora is a diverse but poorly understood component in many forest ecosystems. Detailed information about understory plants for growth forms other than trees is lacking, and there is a dearth of data regarding the effects of environmental factors on the understory. Thus, more attention should be paid to the understory for biodiversity conservation, and the influence variables must be evaluated differently for their vital role in controlling understory vegetation.

\section{Acknowledgements}

This research was financially supported by the Special Fund for Forestry Scientific Research in the Public Interest (Grant No. 201204101). The authors gratefully thank Lin JianYong for plant identification, and Pang ShiLong, He Feng, Zhen Wei, Song XianChong, and Qin ZuoYu for their assistance in fieldwork.

\section{References}

1. XIA F. X., FOUSSENI F., PAN C. G., HE H. J., ZHAO X. $\mathrm{H}$. Effect of overstory on the seasonal variability of understory herbs in primary broad-leaved Korean pine forest of Changbai Mountain. Afr. J. of Biotechnol. 13, (11), 1223, 2014.

2. SOUZA F.M., GANDOLFI S., RODRIGUES R.R. Deciduousness influences the understory community in a semideciduous tropical forest. Biotropica, 46, (5), 512, 2014.

3. BLEBY T. M., McELRONE A., JACKSON R. Water uptake and hydraulic redistribution across large woody root systems to $20 \mathrm{~m}$ depth. Plant Cell Environ. 33, 2132, 2010.

4. SAGAR R., SINGH A., SINGH J. S. Differential effect of woody plant canopies on species composition and diversity of ground vegetation: a case study. Trop. Ecol. 49, 189, 2008.

5. GÓMEZ-HERNÁNDEZ M., WILLIAMS-LINERA G. Diversity of macromycetes determined by tree species, vegetation structure, and microenvironment in tropical cloud forests in Veracruz, Mexico. Botany, 89, 203, 2011.

6. OU Y. D., SU Z. Y., KE X. D., LI Z. K. Vascular ground flora in relation to topography canopy structure and gap light regimes in a subtropical broadleaved forest (South China). Pol. J. Ecol. 60, 463, 2012.

7. CAVARD X., BERGERON Y., CHEN H. Y. H., PARÉ D. Effect of forest canopy composition on soil nutrients and dynamics of the understorey: mixed canopies serve neither vascular nor bryophyte strata. J. Veg. Sci. 22, 1105, 2011.

8. CHANG S. X., WEETMAN G. F., PRESTON C. M. Understory competition effect on tree growth and biomass allocation on a coastal old-growth forest cutover site in British Columbia. Forest Ecol. Manag. 83, 1, 1996.

9. ANDERSON L.J., BRUMBAUGH M.S., JACKSON R.B. Water and tree-understory interactions: A natural experiment in a savanna with oak wilt. Ecology, 82, (1), 33, 2001.

10. NILSSON M-C., WARDLE D. A. Understory vegetation as a forest ecosystem driver: evidence from the northern Swedish boreal forest. Front Ecol. Environ. 3, 421, 2005.

11. KOOCH Y. Ground vegetation as indicator of soil characteristics for an ecological site classification of Southern Caspian forests. Ann. Biol. Res. 2, 360, 2011.

12. SU Z. Y., KE X. D., ZHANG S. J. Vascular plants as indicators of organic carbon gradient in subtropical forested soils. Pol. J. Environ. Stud. 21, (5), 1393, 2012.

13. VAN PELT R., FRANKLIN J. F. Influence of canopy structure on the understory environment in tall, old-growth, conifer forests. Can. J. Forest Res. 30, 1231, 2000.

14. RODRÍGUEZ-CALCERRADA J., MUTKE S., ALONSO J., GIL L., PARDOS J. A., ARANDA I. Influence of overstory density on understory light, soil moisture, and survival of two underplanted oak species in a Mediterranean montane Scots pine forest. Investigación Agraria: Sistemasy Recursos Forestales, 17, 31, 2008

15. MCKENZIE D., HALPERN C. B., NELSON C. R. Overstory influences on herb and shrub communities in mature forests of western Washington, U.S.A. Can. J. Forest Res. 30, 1655, 2000.

16. BARTEMUCCI P., MESSIER C., CANHAN C. D. Overstory influences on light attenuation patterns and understory plant community diversity and composition in southern boreal forests of Quebec. Can. J. Forest Res. 36, 2065, 2006. 
17. HÄRDTLE W., VON OHEIMB G., WESTPHAL C. The effects of light and soil conditions on the species richness of the ground vegetation of deciduous forests in northern Germany (Schleswig-Holstein). Forest Ecol. Manag. 182, 327, 2003.

18. BRENES-ARGUEDAS T., RODDY A. B., COLEY P. D., KURSAR T. A. Do differences in understory light contribute to species distributions along a tropical rainfall gradient? Oecologia, 166, (2), 443, 2011.

19. ZUQUIM G., TUOMISTO H., JOUNES M. M., PRADO J., FIGUEIREDO F. O. G., MOULATLET G. M., COSTA F. R. C., QUESADA C., EMILIO T. Predicting environmental gradients with fern species composition in Brazilian Amazonia. J. Veg. Sci. 25, 1195, 2014.

20. FATHEY R. T., PUETTMANN K. J. Ground-layer disturbance and initial conditions influence gap partitioning of understorey vegetation. J. Ecol. 95, 1098, 2007.

21. DUGUID M. C., FRDY B. R., ELLUM D. S., KELTY M., ASHTON M S. The influence of ground disturbance and gap position on understory plant diversity in upland forests of southern New England. Forest Ecol. Manag. 303, 148, 2013.

22. LI L., WEI S-G., HUANG Z-L., CAO H-L., MO D-Q. Regenerative condition and analysis of spatial distribution pattern of two relic plants in Mao'er shan Mountain, China. Chin. J. Plant Ecol. 36, (2), 144, 2012 [In Chinese].

23. ZHU B., CHEN A-P., LIU Z-L., LI G-Z., FANG J-Y. Changes in floristic composition, community structure, and tree species diversity of plant communities along altitudinal gradients on Mt. Mao'er, Guangxi, China. Biodiversity Science, 12, (1), 44, 2004 [In Chinese].

24. DUAN W-J., WANG J-Y. Vertical distribution pattern and determinant analysis of forest community in Maoer Mountain National Nature Reserve. Ecol. and Environmental Sci. 22, (4), 563, 2013 [In Chinese].

25. WANG J-Y., LI H-F., DUAN W-J., TANG D-M., WANG SN., LIU X-W., HUANG H-Q. Runoff Processes and the Influencing Factors in a Small Forested Watershed of Upper Reaches of Lijiang River. Scientia Silvae Sinicae, 49, (6), 149, 2013 [In Chinese].

26. LI H-F., WANG J-Y., LIU X-W., TANG D-M., LI G-P., WANG S-N. Evaluation on water conservation function of typical forest ecosystems in Maoer Mountain. J. Northwest Forestry University, 27, (1), 50, 2012 [In Chinese]

27. LI K-M., TANG X-Z. Research to diversification and disconcordance of natural broad-leaved forests over different altitudes in Guangxi Mao'er Mountain. Central South Forest Inventory and Planning, 22, (1), 56, 2003 [In Chinese].

28. FRAZER G. W., CANHAM C. D., LERTZMAN K. P. Gap Light Analyzer (GLA), Version 2.0: Imaging software to extract canopy structure and gap light transmission indices from true-colour fisheye photographs, users manual and program documentation. Simon Fraser University, Burnaby, British Columbia, and the Institute of Ecosystem Studies, Millbrook, New York. pp. 1-36, 1999.

29. BULLINER E., HUBBART J. A. An improved hemispherical photography model for stream surface shortwave radiation estimations in a central U.S. hardwood forest. Hydrol. Process., 27, 3885, 2013.

30. BROSOFSKE K.D., CHEN J., CROW T.R. Understory vegetation and site factors: implication for a managed Wisconsin landscape. Forest Ecol. Manag. 146, 5, 2001.

31. WANG X-P., LI X-X. General situation of vegetation in Maoershan Reserve of Xingan County, Guangxi. Guihaia, 6, (1-2), 79, 1986 [In Chinese].
32. MACDONALD S. E., FENNIAK T. E. Understory plant communities of boreal mixed wood forests in western Canada: Natural patterns and response to variable-retention harvesting. Forest Ecol. Manag. 242, 34, 2007.

33. BARBIER S., GOSSELIN F., BALANDIER P. Influence of tree species on understory vegetation diversity and mechanisms involved - A critical review for temperate and boreal forests. Forest Ecol. Manag. 254, 1, 2008.

34. CHÁVEZ V., MACDONALD S. E. Partitioning vascular understory diversity in mixedwood boreal forests: The importance of mixed canopies for diversity conservation. Forest Ecol. Manag. 271, 19, 2012.

35. FAN W-Y., WANG X-A., GAO H., WANG S-X., DUAN RY. Species diversity of forest communities on Ziwuling Mountain of Shaanxi province. Journal of Shaanxi Normal University (Natural Science Edition), 42, (3), 59, 2014 [In Chinese].

36. GAO T., HEDBLOM M., EMILSSON T., NIELSEN A. B. The role of forest stand structure as biodiversity indicator. Forest Ecol. Manag. 330, 82, 2014.

37. ZHANG X-J., GUAN W., LIAO B-W, ZHU N-H., LI L., HE L-X. Comparison on the community characteristics between artificial and natural mangroves in Zhuhai City. Ecol. Sci. 33, (2), 321, 2014 [In Chinese].

38. HU Y. H., SHENG D. Y., XIANG Y. Z., YANG Z. J., XU D. P., ZHANG N. N., SHI L. L. The environment, not space, dominantly structures the landscape patterns of the richness and composition of the tropical understory vegetation. PLoSONE, 8, (11), 1, 2013

39. VAJARI K. A., SHARDAMI H. Plant species diversity in hyrcanian hardwood forests, Northern Iran (Case Study: Mazandaran Province). Ecol. Balkanica, 5, (2), 41, 2013.

40. HART S. A., CHEN H.Y.H. Fire, logging, and overstory affect understory abundance, diversity, and composition in boreal forest. Ecol. Monogr., 78, 123, 2008.

41. NISAR M. F., JALEEL F., WASEEM M., ISMAIL S., ARFAN M. Composition of understory vegetation in tree species of Cholistan desert, Pakistan. J. of Ecol. and the Natural Environ. 5, (10), 278, 2013.

42. YU M., SUN O. J-X. Effects of forest patch type and site on herb-layer vegetation in a temperate forest ecosystem. Forest Ecol. Manag. 300, 14, 2013.

43. AUGUSTO L., DUPOUEY J-L., RANGER J. Effects of tree species on understory vegetation and environmental conditions in temperate forests. Ann. For. Sci. 60, 823, 2003.

44. DU Y. J., MI X. C., MA K. P. Comparison of seed rain and seed limitation between community understory and gaps in a subtropical evergreen forest. Acta Oecol. 44, 11, 2012.

45. VASQUES A., MAIA P., PEDRO M., SANTOS C., VALLEJO V. R., KEIZER J. J. Germination in five shrub species of Maritime Pine understory - does seed provenance matter? Ann. For. Sci. 69, 499, 2012.

46. GOODALE U. M., BERLYN G. P., GREGOIRE T. G., TENNAKOON K. U., ASHTON M. S. Differences in survival and growth among tropical rain forest pioneer tree seedlings in relation to canopy openness and herbivory. Biotropica, 46, (2), 183, 2014.

47. ZHANG C-S., XIE G-D., CHEN L., PEI S., FAN N. Effects of topography and tree structure on the distribution patterns of understory plants in the transitional area between China's southern subtropical zone and the northern edge of the tropical zone. Resource Science. 34, (7), 1232, 2012 [In Chinese].

48. ÁDÁM R., ÓDOR P., BÖLÖNI J. The effects of stand characteristics on the understory vegetation in Quercus petraea and Q. cerris dominated forests. Community Ecol. 14, 101, 2013. 
49. LÉGARÉ S., BERGERON Y., LEDUC A., PARÉ D. Comparison of the understory vegetation in boreal forest types of southwest Quebec. Can. J. Bot. 79, 1019, 2001.

50. FRELICH L. E., MACHADO J-L., REICH P. B. Fine-scale environmental variation and structure of understorey plant communities in two old-growth pine forests. J. Ecol. 91, 283,2003

51. VON ARX G., DOBBERTIN M., REBETEZ M. Spatiotemporal effects of forest canopy on understory microclimate in a long-term experiment in Switzerland. Agr. Forest Meteorol. 166-167, 144, 2012.

52. PRESCOTT C. E. The influence of the forest canopy on nutrient cycling. Tree Physiol. 22, 1193, 2002

53. HEYDARI M., POORBABAEI H., ROSTAMI T., FAGHIR M.B., SALEHI A., HASHMEI R. O. Plant species in Oak (Quercus brantii Lindl.) understory and their relationship with physical and chemical properties of soil in different altitude classes in the Arghvan valley protected area, Iran. Caspian J. Env. Sci. 11, (1), 97, 2013.

54. ADEL M. N., POURBABAEI H., DEY D. C. Ecological species group-Environmental factors relationships in unharvested beech forests in the north of Iran. Ecol. Eng., 69, 1, 2014.
55. BARTELS S., CHEN H. Y. H. Interactions between overstorey and understorey vegetation along an overstorey compositional gradient. J. Veg. Sci., 24, (3), 543, 2013.

56. CHEN Y M., CAO Y. Response of tree regeneration and understory plant species diversity to stand density in mature Pinus tabulaeformis plantations in the hilly area of the Loess Plateau, China. Ecol. Eng., 73, 238, 2014.

57. YAN Y-F., FANG S-Z., TIAN Y., SONG H., DUN X-J. The response of understory plant diversity and nutrient accumulation to stand structure of poplar plantation. Chinese J. of Ecol., 33, (5), 1170, 2014 [In Chinese].

58. REICH P. B., FRELICH L. E., VOLDSETH R. A., BAKKEN P., ADAIR E. C. Understory diversity in southern boreal forests is regulated by productivity and its indirect impacts on resource availability and heterogeneity. J. Ecol. 100, 539, 2012.

59. LU X-L., DING S-Y., YOU L., ZHANG H-Y. Effects of forest canopy structure on understory vegetation characteristics of Funiu Mountain Nature Reserve. Acta Ecologica Sinica, 33, (15), 4715, 2013 [In Chinese].

60. TILMAN D. Competition and biodiversity in spatially structured habitats. Ecology, 75, 2, 1994.

61. CASPER B. B., JACHSON R. B. Plant Competition Underground. Annu. Rev. Ecol. Syst. 28, 545, 1997. 